Article

\title{
Safe Game: Hygienic Habits in Self-Consumption of Game Meat in Eastern Spain
}

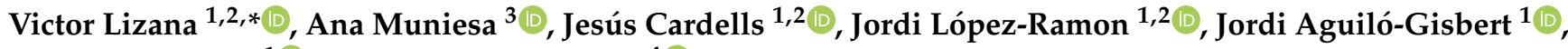 \\ Juan M. Lomillos ${ }^{1}$ (i) and Christian Gortázar ${ }^{4}$ (D)
}

1 Servicio de Análisis, Investigación, Gestión de Animales Silvestres (SAIGAS), Facultad de Veterinaria, Universidad Cardenal Herrera-CEU, CEU Universities, Alfara del Patriarca, PC46115 Valencia, Spain; jcardells@uchceu.es (J.C.); jordi.lopez1@uchceu.es (J.L.-R.); jordi.aguilo@uchceu.es (J.A.-G.); juan.lomillos@uchceu.es (J.M.L.)

2 Wildlife Ecology \& Health Group (WE\&H), Universitat Autònoma de Barcelona (UAB), PC08193 Bellaterra, Spain

3 Departamento de Patología Animal, Área de Sanidad Animal, Facultad de Veterinaria, Universidad de Zaragoza, PC50013 Zaragoza, Spain; animuni@unizar.es

4 SaBio Instituto de Investigación en Recursos Cinegéticos IREC (CSIC_UCLM-JCCM), PC13005 Ciudad Real, Spain; christian.gortazar@uclm.es

* Correspondence: victor.lizana@uchceu.es

Citation: Lizana, V.; Muniesa, A.; Cardells, J.; López-Ramon, J.; Aguiló-Gisbert, J.; Lomillos, J.M.; Gortázar, C. Safe Game: Hygienic Habits in Self-Consumption of Game Meat in Eastern Spain. Foods 2022, 11, 368. https://doi.org/10.3390/ foods11030368

Academic Editor: Arun K. Bhunia

Received: 28 December 2021

Accepted: 25 January 2022

Published: 27 January 2022

Publisher's Note: MDPI stays neutral with regard to jurisdictional claims in published maps and institutional affiliations.

Copyright: (C) 2022 by the authors. Licensee MDPI, Basel, Switzerland. This article is an open access article distributed under the terms and conditions of the Creative Commons Attribution (CC BY) license (https:// creativecommons.org/licenses/by/ $4.0 /)$.

\begin{abstract}
We used anonymous questionnaires to assess the hygienic and sanitary aspects of game meat self-consumption in Eastern Spain as the first step towards a health risk assessment. The survey yielded 472 valid interviews from active hunters. The maximum possible score was 65 points (average $29 \pm 8$; range 1-52). Most participants were men (95\%), but women achieved significantly better scores $(p=0.003)$. Hunters above 65 years old scored significantly lower results than younger groups ( $p=0.007)$. The score increased with the educational level $(p=0.046)$. A $92 \%$ of the collaborators consumed game meat. Veterinary inspection and freezing were irregular among the participants. Most respondents declared carrying the animals in their personal vehicles. Of the dressing process, $61 \%$ of sites were outdoors, $68 \%$ of the participants declared using specific knives, $64 \%$ used the same clothes as in the field, and $42 \%$ used disposable gloves. The most usual way to dispose of the remains was garbage containers (41\%); offal abandonment in the field was 33\%, and 13\% fed domestic animals using the remains. We conclude that public health authorities should increase their interest in the self-consumption of game meat. Clear guidelines about domestic dressing facilities and hygienic habits should be published, these being essential when looking for synergies with hunter associations.
\end{abstract}

Keywords: cross-contamination; game meat; food hygiene; hygienic habits; waste management

\section{Introduction}

Game meat is a particularly appreciated product due to its high culinary [1] and nutritional value (high protein and mineral content and low fat and cholesterol levels) [2-4]. In developed countries, free game is perceived as an organic product $[5,6]$ free of antibiotics and other pharmacological compounds [7]. Sustainable hunting is seen as a way to maintain biodiversity and ecosystems [8], being embraced even by the locavore movement [9]. Rates of consumption are lower than those of domestic species, sometimes related to the difficulties in obtaining it [10]. In Spain, meat from wild game species represents only $2 \%$ of the total meat intake [11], and 59.6\% of game meat is consumed by the hunters themselves or the hunters' inner circle (relatives, friends, and neighbors) [12].

Due to its origin and special processing circumstances, game meat faces its own challenges and may represent a higher sanitary risk in comparison with farm-origin meat. Wildlife does not have the sanitary status achieved by farm production; the animals are 
culled in the field $[13,14]$ and, especially in domestic consumption, carcasses are often eviscerated and skinned under poor hygienic conditions [14-16]. Some issues such as carcass contamination, promoted by bullet trajectory $[13,17,18]$, heavy metals from ammunition remains [19-22], or the time between death and skinning and dressing [13,23], are specific concerns in game meat use.

When animals are correctly shot and dressed, microbiological scores of fresh carcasses may be low, similar to those from domestic species slaughtered in controlled conditions $[6,13,17,24,25]$. Notwithstanding this, levels of biotic contamination can be highly variable due to the shifting conditions in which wild game is killed and processed in the field and their carcasses transported, handled, chilled, and stored $[13,14,16,17,26]$. External factors, such as warm/cold seasons, contribute to microbiological growth as well, being difficult to mitigate [27].

Zoonotic viruses, bacteria, and parasites are commonly found in game carcasses. Health hazards will vary depending on the animal species, the degree of fecal contamination, the time elapsed from death to butchering, and the conditions of dressing and cooling [28-35].

Opinion polls are a common tool to obtain information from stakeholders about many topics. Fish and wildlife management professionals use public opinion and attitude surveys to facilitate an understanding of their constituents [36]. Those surveys have been used to consult attitudes towards hunting and fishing [37-39], game meat consumption [38,40], or the opinion about governmental wildlife agencies [41]. Public health authorities also use this methodology to obtain information about the food hygiene practices of their citizens [42,43].

We used opinion polls to assess the hygienic-sanitary aspects of game meat processing and self-consumption in the Valencian community, Spain, as a first step to obtain a human and environmental health risk assessment.

\section{Materials and Methods}

\subsection{Study Area}

The present study was conducted in the Valencian community (Eastern Spain) (see Figure 1), a 23,255 $\mathrm{km}^{2}$ autonomous region with 4.9 million inhabitants [44]. The region is divided into 31 districts and 542 municipalities, with four cities over 150,000 inhabitants (Valencia, 786,000; Alicante, 335,000; Elche, 234,000; Castellon, 167,500) and another 24 smaller ones between 30,000 and 85,000. Most of the population is located on the Mediterranean coastland; meanwhile, the inland population density is low.

The target of the survey was hunters, estimated at 36,829 [45]. Although hunting is not allowed in the whole territory (it is forbidden in protected areas, densely populated districts, and buffer zones surrounding infrastructure and isolated buildings), 19,033 km² ( $82 \%$ of the total) is enabled for this activity [46]. Except for wild waterfowl, which are more common in coastal wetlands, most animals are hunted in the inland counties with $90 \%$ woodland areas [46].

In the Valencian community, veterinary inspection is mandatory for those hunting events that plan to sell the meat. The carcasses generated should be primarily inspected by a veterinarian in the field, then transported to game slaughterhouses in neighboring regions (because there are no specific slaughterhouses in the territory), where a second veterinary inspection will take place. Under the Regional Decree 201/2017 [47], individual hunters can sell small amounts of game meat to the final consumer or to a commercial establishment selling directly to the final consumer, but the requirements (e.g., authorized veterinarians, local slaughterhouses focused on game meat, forms, taxes) have not been completely implemented yet. Hunters do not have an obligation to pass a veterinary inspection of the carcasses (except for Trichinella spp. in wild boar) if the intention is self-consumption. 


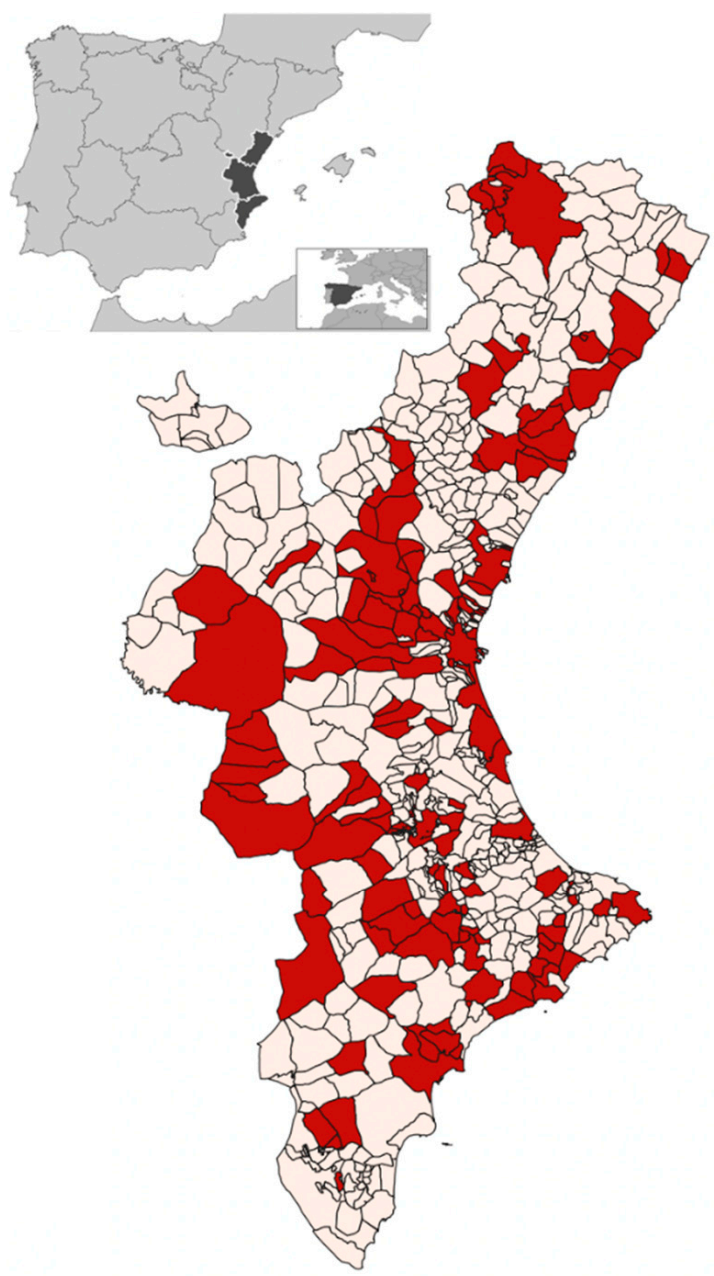

(a)

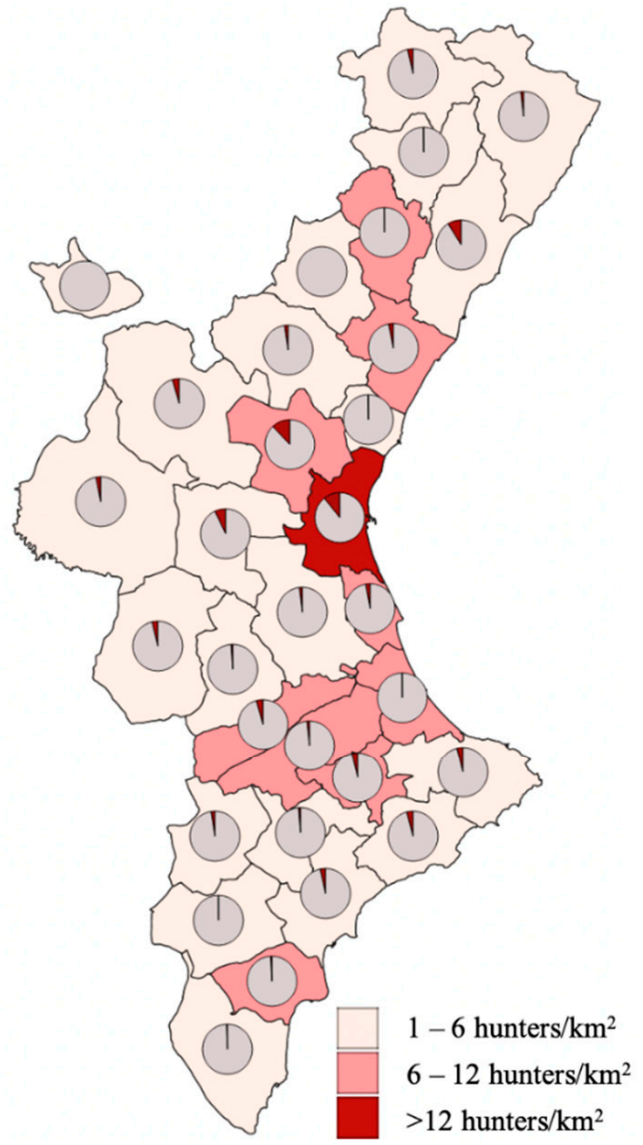

(b)

Figure 1. Survey distribution throughout the study area: (a) surveyed municipalities; (b) survey proportion per county and hunter density.

\subsection{Opinion Poll}

Structure: The survey forms were composed of 35 questions (see Appendix A). Some of them admit multiple-choice answers (e.g., species harvested, hunting modalities), while others are mutually exclusive (such as gender or level of studies). Four different content blocks form the questionnaire:

1. Consent to participate: Prior to the main questionnaire, potential responders had to agree by marking a specific box and were informed about the voluntariness, topic, and goal of the survey and about the aim of publishing the results at the end of the study. They were also informed that their data would be treated anonymously.

2. Generalities: Questions about personal information (gender, age, level of education, profession, place of residence) and hunting activity (animal species, modalities, location).

3. Game meat consumption: Species consumed, amount of meat, culinary preparation.

4. Dressing and butchering: Veterinary inspection, game transport conditions, facilities and tools used, protective clothes and equipment, cleaning processes, and waste disposal.

The third block was established and inspired by the model of structural, hygienic, and transport requirements in game meat processing used by Vinhas [48] and Vieira-Pinto [15].

Panel of experts: The first draft was sent to a selected group of researchers and public officers, chosen because of their relevance and knowledge in food hygiene, wildlife 
management, zoonoses, public health, and hunting practices. After several meetings and corrections, a fourth version of the questionnaire was considered appropriate to the survey goals.

Validation: Once the consensus draft was ready, it was given to several trusted hunters to evaluate the comprehension level of the question pool to detect if any information considered relevant by the hunters was missed. The survey was validated with minor modifications regarding the meaning of some abbreviations, which were modified in the final version.

Survey: Hunters were randomly selected to achieve regional representativeness. A physical copy of the questionnaire was given to the collaborators. However, no copies were offered to those answering on the internet, as we tried to avoid non-desirable behaviors such as poll crashing [36] or undesired responses from hunters belonging to other regions. To better comply with the obligations mentioned in Regulation (EU) 2016/679 on personal data protection, the form was anonymous. In addition, we consider that an anonymous questionnaire will achieve a higher level of truthful answers

\subsection{Statistical Analysis}

To evaluate potential differences in social-educational background and hygienic practices, a scoring system was established using the model created by Vieira-Pinto [15] as a starting point. This score values the hygienic procedures, facilities, supplies, and waste disposal of the interviewed hunters. The distribution of each variable was studied with the Kolmogorov-Smirnov test. Non-parametric tests were used for those parameters with a non-normal distribution $(p<0.05)$, using the Mann-Whitney U-test when comparing among two categories and the Kruskal-Wallis test to compare more than two categories.

The minimal sample size was established in 381 polls for a survey based on 36,829 hunting licenses for a 95\% confidence level and 5\% precision with EPIDAT v.4.2 software [49].

\section{Results}

The survey period began in January 2018 and ended in February 2020. A total of 516 questionnaires were filled out, but $44(8.52 \%)$ were rejected due to missing answers or because the respondents lived out of the surveyed area. The final amount of 472 valid interviews was considered enough for the targeted population. Questionnaires from 128 municipalities were held, representing $23.8 \%$ of the total number of municipalities into which the territory is divided (Figure 1).

The maximum possible score, corresponding with optimal hygienic behavior, is 65 points. The average score achieved by the surveyed hunters was 29 points (highest 52 , lowest 1 ) with a deviation of 8 points (median and interquartile range, because data distribution, studied through the Kolmogorov-Smirnov test, is not normal, $p=0.030$ ). An overwhelming majority of participants in our survey were men (95.1\%), but women achieved the best scores $(p=0.003)$. Among ages, $18.8 \%$ of the participants were between $18-30,44.4 \% 31-50,27.5 \%$ 51-65, and 9.3\% >65 years old. Age-related differences in the hygiene score were marginally significant $(p=0.053)$. However, when comparing the results from $>65$ y.o. hunters with those from the rest of the interviews, the result was $p=0.007$. Referring to educational background, $6.1 \%$ had no studies, 37.8\% had primary education, $39.3 \%$ had secondary-professional education, and $16.6 \%$ had university degrees. The total score value increased significantly $(p=0.046)$ as the educational levels got higher.

The largest consumed big game species in our survey was wild boar (Sus scrofa) (22.5\%). Among small game, wild rabbit (Oryctolagus cuniculus) $(24.4 \%)$ and red-legged partridge (Alectoris rufa) (20.7\%) are the most popular ones. The preferred hunting modalities (90.6\%) involve hunting dogs or other assistant animals (ferrets or raptors). In total, $92.1 \%$ of the collaborators consume the hunted prey; $40 \%$ of them allocate game meat to their own families, $9.4 \%$ give the meat to relatives, friends, or neighbors, and $48.4 \%$ to both previous assumptions. Only $2.1 \%$ of the surveyed hunters declared selling the meat. Most hunters $(59.3 \%)$ cooked it for consumption. Preparations such as raw sausages or salt-cured meat 
are less common (16\% and 10.1\%, respectively). Pickled preparation (13.7\%) is also common, especially among small game hunters, while other options are scarce (smoked $(0.4 \%)$, pâté $(0.1 \%)$, or raw $(0.3 \%))$. Among the $7.9 \%$ who do not consume their game meat, the main situation was the lack of time for meat dressing $(69.5 \%)$, rejection $(19.5 \%)$, lack of culinary interest $(8.7 \%)$, or health problems $(2.17 \%$ with uric acid rising).

Sanitary behaviors such as veterinary inspection or freezing were irregular among the participants. Only $22.4 \%$ always resort to a veterinarian, while $11.9 \%$ do it "usually" and 13.4\% "not normally". Most results (34\%) are for those who approach a veterinarian only for Trichinella diagnosis after hunting wild boar, while 18.2\% (essentially small game hunters) admitted to never consulting a veterinarian. The need to freeze game meat before consumption is felt as mandatory for some hunters; $40.6 \%$ declared freezing it "always" while $48.2 \%$ do it "usually". A lower $7.6 \%$ admitted putting the meat in the freezer "occasionally" and only 3.5\% "never" do it. Those hunters who declared freezing game meat were additionally asked about the period they let the meat freeze. Of these, $17.3 \%$ freeze the meat for less than 1 month, 39.1\% between 1 to 2 months, $34.5 \%$ between 2 to 6 months, and $9.1 \%$ more than 6 months.

Focusing on cross-contaminations, several questions were asked about the possible weaknesses in meat processing, personal hygiene, cleaning protocols, or suitability of dressing facilities. About hunted-animal transport, most respondents $(74.4 \%)$ declared carrying the animals in their personal vehicles; $13.1 \%$ prefer to move them in the back of an open pickup or open trailer; $8.5 \%$ transported the carcasses in the back of a pickup with a canopy or an enclosed trailer. The best option from a food safety point of view, an exclusive vehicle or trailer with a refrigeration system, was available for only $3.6 \%$ of the surveyed hunters. Only $3.2 \%$ of the interviewed hunters had authorization to transport animal by-products (ABP) not intended for human consumption. In fact, except for those involved in farming, the meat industry, or animal health, this terminology was unknown. About evisceration, $19.7 \%$ of the interviewed hunters declared dressing the prey immediately in the field. For $28.7 \%$, the time elapsed was less than $2 \mathrm{~h} ; 2$ to $4 \mathrm{~h}$ for $27.7 \%, 4$ to $6 \mathrm{~h}$ in $13.5 \%, 6$ to $8 \mathrm{~h}$ in $4.1 \%$, and $5.1 \%$ exceed over $8 \mathrm{~h} ; 81.8 \%$ of respondents owned their own dressing facilities, $7 \%$ performed the process in another person's place, $7.8 \%$ in a collective property (hunting clubs), $1.5 \%$ were done in public places (commonly obsolete municipal slaughterhouses granted by local authorities), and $1.9 \%$ of the answers indicated dressing the animals directly at the killing site. Of the dressing sites, $60.8 \%$ were outdoors (killing site, yards, or patios), while 39.3\% were indoor installations. Only 32.3\% of the facilities were specifically dedicated for game dressing, while the rest had shared uses with other activities (yard 19.3\%, storage 15.7\%, garage 15.5\%, workshop $1.7 \%$ ) or even with activities, allowing the contamination of food and meals or human contagion (pantry $5.7 \%$, kitchen $5.3 \%$, meeting place $3.2 \%$ ). Of the hunters, $91.6 \%$ had access to safe water in their dressing facilities, but only $54.8 \%$ (mainly those who dress the animals in their own homes) had hot water. Of the facilities, $5.9 \%$ had water not coming from supply systems but from irrigation and rainwater tanks. In $2.5 \%$ of the situations, the facilities had no access to water at all. Regarding carcass position when dressing and cutting tool utilization, $53.8 \%$ of hunters declared suspending the animals with a hook or a similar device, $36.4 \%$ eviscerated the animals on a table or bench, $4.9 \%$ displayed the bodies on the ground over plastic sheeting, $3.4 \%$ on a pavement floor, and $1.5 \%$ directly on a dirt floor; $68.1 \%$ of the participants declared using a specific set of knives for dressing, while the remaining $31.9 \%$ admitted using the same knives for other purposes. Some questions were made regarding the light sources in the dressing facilities. Of the responders, $22.4 \%$ depended completely on sunlight, while the rest had access to artificial sources. Incandescent bulbs were the most common devices (34.9\%), followed by LED lights (14.8\%) and halogen tubes $(14.6 \%)$, while $9.5 \%$ used a combination of natural and artificial sources and a marginal $3.8 \%$ used portable manual devices (such as torches and headlamps). Given the potential for insects and rodents to contaminate food [50], the interviewed hunters were asked about the protective measures available in their dressing facilities. Regarding insects, the most 
common devices were insect gauzes in windows (34.5\%), adhesive traps $(8.7 \%)$, light traps $(8.5 \%)$, and insecticide sprays $(4.4 \%)$. Even so, $43.8 \%$ of the responders did not use any device to control insects. Concerning rodents, spring traps were the preferred devices $(14.1 \%)$, followed by poison pellets $(12.7 \%)$, glue traps $(5.6 \%)$, cage traps $(5 \%)$, and, finally, cats $(0.8 \%)$. Most of the hunters referred to not using pest control strategies $(61.8 \%)$. About cleaning protocols, $35.3 \%$ of users informed hosing down their facilities after dressing, while $24.5 \%$ prefer to mop the floor. The combination of both (hosing down and mopping) was also popular $(14.9 \%)$. The use of scouring pads $(9.3 \%)$ was referred when cleaning sinks, tables, and other surfaces. Dry brushing was the option for only $1.5 \%$ of hunters. Combinations of several of the previous procedures were reported in $10.5 \%$ of the answers, and $3.9 \%$ did not clean the dressing site in any way. About disinfectant use, the most common ones were bleach $(27.4 \%)$, soap $(8.4 \%)$, and floor cleaners $(4.8 \%)$. Other options were marginal (ammonia $0.2 \%$, caustic soda $0.4 \%$ ). Almost half of the interviewed subjects $(47.9 \%)$ do not use any kind of substance but water. Regarding the clothes they used during the dressing. $63.7 \%$ use the same clothes as in the field and $15.5 \%$ use covering clothes (such as a lab coat or a coverall) over the usual wear; $16.4 \%$ changed all their clothes to use specific clothing and only $4.4 \%$ use specific footwear (rubber boots). To evaluate the risk of suffering cuts, stabs, spills, or inhalations, a question was made about the use of personal protective equipment (PPE). The most common items were disposable gloves $(42.1 \%)$, while other equipment was used by less than $5 \%$ of participants (leather gloves $4.6 \%$, steel mesh gloves $4 \%$, facial mask $2 \%$, face shield $1.8 \%$ ). Some hunters (5.5\%) used more than one item simultaneously, disposable gloves and steel mesh gloves being the most common combination (1.7\%). Most answers (44.9\%) confessed to not using protective equipment at all. About personal hygiene, they were asked about the possibility of washing their own hands during and after meat processing in the slaughter facility; $45.4 \%$ declared having access to running water, $8.9 \%$ had access to water, but from an uncertain origin (e.g., rainwater, water well), and $2.3 \%$ had no option to wash their hands. In addition, $36.9 \%$ used soap and $6.4 \%$ hand sanitizers or disinfectants.

Regarding waste management, the most usual way to dispose of the remains was municipal garbage containers (41.3\%). In 33.2\% of cases, the answers showed the abandonment of offal and other remains directly in the field (11.1\% were buried, $11.5 \%$ were left in an open area, and $10.6 \%$ were hidden in a pit cave or gully). Of the interviewed hunters, $12.8 \%$ declared to use offal to feed domestic animals (dogs $12.1 \%$, cats $0.34 \%$, pigs $0.34 \%$ ). In $7.9 \%$ of the answers, the organic remains were disposed of in carcass containers (associated with the farming industry); $4.4 \%$ of users declared leaving the offal in vulture feeding stations, and a marginal $0.34 \%$ use incineration to dispose of the remains. Wastewater was eliminated through collective water networks by most hunters (53.5\%); 30.2\% released the contaminated water into rivers, ravines, or crop fields, $7.8 \%$ did not know the destination, $7.6 \%$ had access to a specific organic residue water treatment plant, and $0.8 \%$ stored the wastewater in septic tanks.

\section{Discussion}

This survey offers a wide spectrum view towards private game meat self-consumption, a scarcely studied topic concerning both wildlife management and public health perspectives. Although some key aspects cannot be evaluated by using opinion polls, such as the efficiency of dressing, hygiene and cleaning protocols, the time span needed to reach refrigeration/freezing temperatures, or the microbiological status, it still constitutes a useful tool for studying the social aspects implied, and it allows us to detect deep-seated procedural errors, training needs, and deficiencies in the facilities.

Despite the openness of game activity towards women in recent decades, it continues to be a mainly masculine practice [51,52], and only $1.15 \%$ of hunters from our study area are women [53]. This fact explains why only $4.9 \%$ of the surveyed people were huntresses. The marks achieved by women in our study were significantly higher than those of men. Several previous surveys have demonstrated a greater efficiency and dedication from women 
towards hygienic procedures [43] and a bigger concern about potential food safety risks and safer practices than men $[42,54,55]$. Our survey only detected marginally significant differences among age groups when compared altogether. However, in accordance with previous research [56], which has found more food safety malpractices in older adults, we compared the score achieved by the $>65$ y.o. group with the rest of the participants, finding a significantly lower total score in the oldest group. Consistent with previous studies, the level of education is a relevant factor in the final achieved score. People with very little or no educational background have a low understanding of food safety issues [57]. A higher level of formal education creates awareness in ensuring safer and more hygienic practices $[58,59]$. A higher awareness of potential risks is reached by people with university studies, with increased knowledge among those from health-related fields [55,60]. Experience can play an important role too, and it has been shown that training leads to better results in microbiologic contamination in game meat processing [25].

In reference to hunted species, our results are consistent with the official game statistics, showing that the most consumed game is also the most abundant one. Wild rabbit is the most hunted and consumed small game species (430,931 individuals-24.4\% answers), red-legged partridges for birds $(89,049-20.7 \%)$, and wild boar for big game $(26,832-22.5 \%)$ [61]. In Spain, most authorized hunting modalities involve the utilization of assistant animals. Ferrets, raptors, and, especially, different dog breeds are used to help the hunters track, chase, and catch wild prey. Bite-borne microbiological contamination is a collateral effect of this utilization and a concern to food hygiene goals [62]. Unlike other parts of the country, the Valencia region does not have a culinary tradition in preparing sausages or cured game meat. This cultural behavior works as a self-protective strategy against some pathogens (such as the hepatitis E virus, toxoplasmosis, or trichinellosis) that can be transmitted by raw and undercooked meat [31,63-65]. Specific concerns between wild boar meat consumption and Trichinella spp. transmission were expressed by some hunters. Different strategies (or combinations of several procedures) are commonly carried out to reduce the risk of transmission, such as cooking the meat, freezing the carcasses for at least 2 months, and veterinary checking for Trichinella larvae.

Geographic locations where the animals have been shot can be notably far from the dressing facilities. Thus, transport conditions can be challenging to assure meat safety. The safer option (i.e., an exclusive vehicle with refrigeration) was selected by only $3.6 \%$ of the surveyed hunters, thus evidencing the lack of proper transport systems, comprising a potential risk for meat contamination. Furthermore, the most popular option (i.e., personal vehicles) may represent a supplementary public health risk due to the difficulties of cleaning up fluid spills, the utilization of the vehicle for private purposes, and the contamination of personal items sharing the space. European regulations show some legal uncertainties regarding the scope of the rules on ABP from wild game. Regulation (EC) No 853/2004 admits that, if good hunting practices are observed, intestines and other body parts of healthy wild game hunted in their natural habitat may be disposed of on-site. To ensure the health status of the animal, a new figure of "trained hunter" was created, understood as a person with additional training, able to make an on-site evaluation of animal health before veterinary inspection [66]. The Valencia Community Regional Order 3/2019 excluded this possibility, declaring graduates in veterinary medicine as the only professionals able to check the sanitary status of game animals [67]. Regulation (EC) No 1069/2009 considers the wild animals when suspected of being infected with diseases transmissible to humans or animals as Category 1, while the carcasses and body parts of healthy game animals which are fit for human consumption but not intended for commercial sale are classified as Category 3 [68]. All those regulations are focused on game meat commercialization, while self-consumption is not mentioned and could be considered a loophole and a threat to human health. The low rate $(3.2 \%)$ of hunters with the authorization to transport ABP shows an extensive lack of knowledge about this regulation. The time elapsed between the death of the animal and the evisceration can be highly variable, depending on different factors such as the distance from the field to the dressing facilities or the hunting modality 
(it is longer in collective hunting, where participants are not allowed to leave their positions until the end of the hunt due to safety reasons [69]); $22.7 \%$ of hunters declared exceeding the time span considered to be critical for limiting bacterial spread from unbroken guts [70]. If fecal contamination is present because of abdominal shoots, the combination with high carcass temperatures for several hours presents a potential risk for human health. In fact, the contamination of game carcasses by feces and subsequent invasion by enteric pathogenic bacteria is rather common in game because, in general, animals are eviscerated and skinned under insufficient hygienic conditions $[15,70,71]$. Butchering and dressing animals are potentially risky processes in which the handler comes into contact with organic material and body fluids, potentially carrying disease-producing microorganisms [72] that can be transferred to surfaces and tools while handling meat [73]. There is an evident need for training in hunter communities about personal hygiene, protective measures, and the use of specific protective gear during game meat processing. The lack of use of these protective supplies has been demonstrated as a risk factor to people involved in dead animal handling [74-76]. Due to their high exposure to wild animals, hunters and butchers of wild game (among other collectives) are commonly exposed to animal pathogens, being the origin of contagion to other people. Public health monitoring programs looking after wildlife diseases should focus on those groups $[77,78]$. Lighting is a relevant factor for proper animal dressing in order to detect alterations that lead to discarding affected areas and performing the operations in a safe way. Nearly a quarter of the surveyed users (normally associated with outdoor facilities) depended totally on sunlight, which should be a matter of concern. Additionally, there is room for improvement in those facilities using incandescent bulbs, which should be properly enclosed to prevent glass contamination in meat in case of breakage [79]. Taking as a reference the European standard UNE 12464-1:2011 about the lighting of workplaces, the indoor dressing facilities must reach a 500 LUX light level [80], an unknown factor for self-consumers. There is room for improvement in dressing facilities because most of them are located outdoors; the facilities are then exposed to contamination by insects and dust [48] and are also used for other activities, in close contact with food and people. Insects and rodents are the origin or vehicle of microorganisms that are able to contaminate food and processing sites, being able to transmit Salmonella spp. [81,82], Campylobacter spp. [83], Yersinia spp. [84], and Cryptosporidium paroum [85], among others. For this reason, it is considered essential to implement pest control protocols, not only by access prevention or direct persecution but also by ensuring that control methods (traps, poison, cats) do not constitute a significant health hazard in themselves. Under proper maintenance and control, some measures are considered desirable, such as insect gauzes, insect light traps, or rat poison, while others should be discarded due to their implicit risk of becoming a source of contamination. Most common insecticide sprays used in domestic dressing facilities are not focused on the food industry, so the chemicals could remain on surfaces where raw food materials are displayed because of the absence of further studies about suspension periods and a lack of proper training in the users. This situation constitutes a potential source of toxic exposure through food intake [86]. Adhesive traps could be useful for early insect presence detection [87] but should not be used as a device to control pest populations. On a general basis, all animal access to dressing facilities must be avoided, thus impeding the entry of domestic cats and disqualifying felines as valid rodent controllers [88]. The quality of cleaning water access and lack of heating devices should be matters of concern. Surface and tool cleaning with hot water is a common method to reduce the pathogenic bacteria related to meat processing $[89,90]$. However, of the $91.5 \%$ of respondents who declared having water in their dressing facilities, only $54.8 \%$ had hot water and this does not imply reaching temperatures high enough to reduce bacterial presence in an effective way. The common practice of cleaning the carcass during dressing increases some bacterial counts [25]. Future actions should be taken to train the target population, aiming at domestic infrastructure improvement. Inadequate decontamination procedures applied to potentially contaminated utensils may present further risks of microbial contamination in subsequent meal preparations, thereby reducing the shelf life and 
product safety [56,91,92]. Almost one-third of the surveyed hunters declared using the dressing knives in other activities. The position of the carcasses when dressing can create additional contamination of the derived meat. Most surveyed hunters $(90.2 \%)$ displayed behaviors considered appropriate, hanging up the carcasses (53.8\%) [48] or putting them on a specific table or bench (36.4\%). Animal dressing on the floor (on a plastic sheeting (4.9\%) or pavement surface $(3.4 \%)$ ) can be considered minor options, with the worst-case scenario (evisceration on a dirt floor) [15] as anecdotical (1.5\%). Cleaning protocols are key aspects of hygienic meat processing. It is essential to analyze the procedures to detect weaknesses that may signify a cross-contamination risk from inadequately sanitized facilities, health hazards due to bacterial proliferation, or the apparition of persistent bacteria [93]. Floor cleaning through hosing down or mopping may be seen as correct practices, but this can generate droplets and therefore should be discouraged during and immediately prior to production periods [94]. Using only water (the case of almost half of the interviewed users) would be useful only if high pressure is used. A proper combination of kinetic energy through the impact of water droplets, time, and temperature is enough to remove biofilms [95]. However, if those conditions are not achieved, then protein and fatty organic residues will remain, allowing the persistence of microorganisms. Bleach and its derivates are some of the most effective home sanitizers available, and they are also used in the meat industry $[96,97]$. Thus, its popularity in being used alone or combined with other disinfectants is evaluated as desirable. As commented previously about insecticides, disinfectants used for cleaning surfaces or tools in contact with food should be authorized for the food industry to guarantee the safety of the derived products.

Surfactants present in soap, detergents, and floor cleaners enable the removal of fatty organic remains and affect the cellular membranes of the microorganisms [98]. The combined use with a sanitizer such as bleach is the best practice. Inappropriate practices, such as dry brushing, which often results in the generation of bioaerosols, transferring floor microorganisms to food preparation surfaces $[99,100]$; the total absence of cleaning interest is a minor point in this survey.

Waste management is one of the main problems detected in the survey. Trash containers were the most common way to dispose of solid residues derived from game dressing and butchering (41.3\%), but those structures are accessible to synanthropic mammal species such as brown rats (Rattus norvegicus) [101] or red foxes (Vulpes vulpes) [102], who can feed on the remains, thus being a source of disease spreading. It is known that free-living cats (Felis catus) tend to visit rubbish bins regularly [103], closing the life cycle of toxoplasmosis. Environmental contamination with oocysts of Toxoplasma gondii has been found surrounding rubbish deposits associated with feral cats [104]. Toxoplasmosis infection rates in local wild boar (the most killed big game) is 14.1\% [105]; hence, organic remains are potentially risky; $33.2 \%$ of answers disclosed the abandonment of offal and other remains directly in the field. This method, being legal in some EU states (Regulation (EC) No 853/2004), is a source of contamination and a way to help parasites complete their life cycles [15,106-108]. Three species of Trichinella have been found in Spain (T. spiralis, T. britovi, and T. pseudospiralis) [109]. Under proper climatic conditions, infective Trichinella larvae can remain viable in carrion for a long period [110,111], acting as a source of infection for mammal scavengers [33] and synanthropic carnivores [112]; 12.8\% of surveyed hunters use the remains to feed domestic animals (essentially dogs but also cats and pigs). Wildlife is a reservoir of a plethora of pathogens that is able to affect domestic species, for example, T. gondii [105], Aujeszky's virus [113], Alaria alata [114,115], Echinococcus granulosus, transmitted from ruminants' offal [116], and E. ortleppi from wild boar viscera, accessible to dogs (Canis lupus familiaris) [117]. Weaknesses in biosecurity protocols, particularly in small pig farms, can facilitate disease transmission from wild boar populations. African swine fever, because of its virulence and the current epidemiologic situation in continental Europe, is one of the most relevant concerns in this regard [118]. Some waste management practices, such as offal incineration [119], safe disposal in carcass containers [116] (Jiménez et al., 2002), or avian scavengers [120], are considered effective strategies to control disease dispersal. Only 7.9\% 
had access to carcass containers (normally associated with farm activity). Although Spain hosts the most important vulture breeding populations of all European countries [121], only $4.4 \%$ of collaborators use vulture feeding stations as places to leave the remains of game dressing. Vultures may contribute to the removal of ungulate infectious diseases due to their resistance to most pathogenic microorganisms [120]. Although being very effective in reducing biological contamination, incineration $(0.34 \%)$ can be considered anecdotal. About wastewater, only $7.6 \%$ of the hunters interviewed declared having access to a specific organic residue water treatment plant. Most of the cases (53.5\%) used the collective water network, and $30.2 \%$ released the polluted water to bodies of surface water or farmlands. Water has been proved to be an effective vehicle for animal-human shared pathogens such as Mycobacterium spp. [122-124] Toxoplasma gondii [125], or hepatitis E virus [126,127]. Uncontrolled wastewater coming from slaughterhouses can pollute water bodies with a plethora of parasites [128].

\section{Conclusions}

Public health authorities should increase their interest in topics regarding the selfconsumption of game meat. There is an imperative need to provide formal training in good hygiene practices during all the steps of game meat preparation and handling. Specific cleaning protocols must be established, especially regarding the avoidance of cross-contaminations. Carcass containers must be available for game animal by-products to prevent environmental contamination and disease dissemination. Clear guidelines about domestic dressing facilities must be published to allow the users to improve their own facilities.

Specific health monitory programs should be implemented to detect wildlife diseases in the collective of hunters $[129,130]$ to provide a quick response before any contagion and spreading to other people. It is essential to look for synergies with hunters' associations, federations, and other stakeholders to promote a proactive approach. Additionally, it could be relevant to reevaluate the situation in the COVID-19 post-pandemic context due to the general use of personal protective equipment and disinfectants and a potential improvement of awareness and self-protection measures.

Author Contributions: C.G., V.L. and J.C. conceived the study; C.G., V.L., J.C. and J.L.-R. designed the questionnaire; J.C., J.L.-R., J.A.-G. and J.M.L. validated the questionnaire; V.L. performed the investigation; A.M. analyzed the data; V.L., A.M. and J.L.-R. wrote the original draft; C.G., J.C., J.A.-G. and J.M.L. reviewed and edited the manuscript., J.C. achieved funds; C.G. supervised the process. All authors have read and agreed to the published version of the manuscript.

Funding: This research received no external funding.

Informed Consent Statement: Consent to participate was obtained from all the respondents involved in the study.

Data Availability Statement: Data sharing not applicable.

Acknowledgments: Hundreds of people have, literally, collaborated in this survey. Not only the hunters themselves, who filled in the questionnaires but also other people who have linked hunters and researchers, making it possible to reach the sample size required for this study. Regarding this point, Miguel Angel Arnau and Carlos Oller deserve a special mention for their involvement in this study. Paul Schnyder gave valued help by conducting the English editing of the original manuscript. We thank the editor and two anonymous reviewers for their constructive comments.

Conflicts of Interest: The authors declare no conflict of interest. 


\section{Appendix A}

\section{Questionnaire Model}

(Score and prompts to future researchers are indicated in italics; these prompts must be removed in order to provide a raw questionnaire to future participants).

\section{Hunting activity and game meat consumption survey}

The goal of this survey is to evaluate the factors related to hunting activities, the groups that practice it, the main target species, and habits about game meat handling and use. By completing it, you voluntarily agree to transfer the information, which will be used for research and scientific dissemination. Although you will be asked for some personal data, it is an anonymous survey, so you should not provide any type of information that allows your individual identification, sticking to the questions that are posed in the survey. That is why we ask that you should not provide any unsolicited information (such as your name, ID, or signature) in this document. Since the data requested are dissociated, that is, the information obtained cannot be associated with a specific or determinable person and no type of file will be generated that contains data that allow the identification of the participants, the application of the Law on Data Protection will not take place in the present case.

The organizing entities of this study thank you for your collaboration and invite you to consult the results once they are published.

I have read and understand the conditions of participation in this survey (mark with an X)

Date

Block I. Generalities of the Game activity

1.- Gender

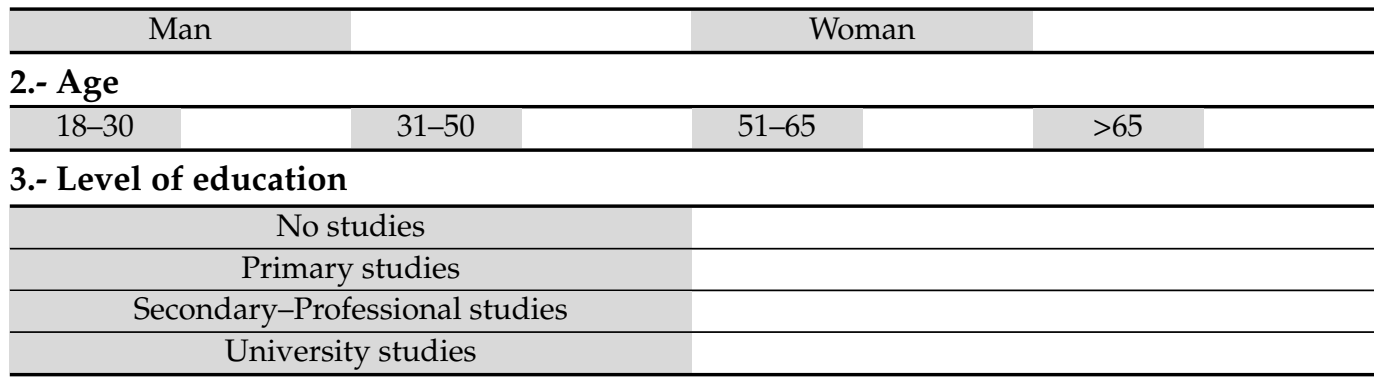

\section{4.- Work activity:}

4.1.- Do you have any relation (employment/familiar) with livestock management? YES NO

4.2.- If affirmative, what kind of relation?

\section{5.- Place of residence:}

\section{6.- Municipalities where you mainly practice hunting}

(a) Municipality 1

Province

(b) Municipality 2

Province

(c) Municipality 3 Province

\section{7.- Hunting modalities \& prey}

\begin{tabular}{ccc}
\hline $\begin{array}{c}\text { Driven } \\
\text { hunting/Battue }\end{array}$ & Stalking & Stand hunting \\
\hline $\begin{array}{c}\text { Wing shooting } \\
\text { without dogs }\end{array}$ & $\begin{array}{c}\text { Small game } \\
\text { hunting with dogs }\end{array}$ & Calling decoy \\
\hline Ferret & Falconry & $\begin{array}{c}\text { Dog without } \\
\text { weapon }\end{array}$ \\
\hline
\end{tabular}




\begin{tabular}{lll}
\hline Wild boar & Rabbit & Woodcock \\
\hline Red deer & Hare & Pheasant \\
\hline Fallow deer & $\begin{array}{l}\text { Red-legged } \\
\text { partridge }\end{array}$ & Duck \\
\hline Roe deer & Quail & Fox \\
\hline Corsican mouflon & Starling & Magpie \\
\hline Spanish wild ibex & Wood pigeon & Turtle dove \\
\hline Barbary sheep & $\begin{array}{l}\text { Others (which } \\
\text { ones?) }\end{array}$ & \\
\hline
\end{tabular}

Block II. Game meat intake

8.- Do you regularly eat the meat of the animals you hunt?

YES

NO

\section{1.- If not, why?}

Game meat is disgusting/repulsive

Preparing game meat is too laborious

You have eaten game meat for so long that it is

boring nowadays

\section{2.- If you consume the meat}

8.2.1.- What species do you consume? (Ordered by weight)

\begin{tabular}{c}
\hline $1 .-$ \\
\hline $2 .-$ \\
\hline $3 .-$ \\
\hline
\end{tabular}

8.2.2.- What is the destination of the meat? (If more than one situation is possible then indicate 1st, 2 nd, and 3rd by relevance).

Self-consumption and inner circle

Given to friends, neighbors, acquaintances ...

Selling

\subsection{3.- Do you freeze game meat before consumption?}

\begin{tabular}{|c|c|c|c|c|}
\hline No, never & 0 & \multirow{6}{*}{$\rightarrow$} & & \\
\hline Not normally & 0 & & & \\
\hline Usually & 1 & & $\begin{array}{l}\text { Less than } 1 \\
\text { month }\end{array}$ & 1 \\
\hline \multirow[t]{3}{*}{ Always } & 2 & & $\begin{array}{l}\text { Between } 1 \\
\text { and } 2 \mathrm{~m} .\end{array}$ & 2 \\
\hline & & & $\begin{array}{l}\text { Between } 2 \\
\text { and } 6 \mathrm{~m} .\end{array}$ & 3 \\
\hline & & & $\begin{array}{l}\text { More than } \\
6 \text { months }\end{array}$ & 4 \\
\hline
\end{tabular}

8.2.4.- How do you gastronomically prepare game meat for consumption?

\begin{tabular}{ll}
\hline Cooked & 3 \\
\hline Raw-dried sausages & 0 \\
\hline Salt-cured & 0 \\
\hline Smoked & 1 \\
\hline Pâté & 2 \\
\hline Pickled & 2 \\
\hline Raw & 0 \\
\hline
\end{tabular}


Block III. Hunted Animals Management

9.- Do you call for veterinary inspection after hunting activities?

\begin{tabular}{ll}
\hline Always & 2 \\
\hline Usually & 1 \\
\hline Only for Trichinella diagnosis when hunting wild boar & 1 \\
\hline Not normally & 0 \\
\hline Never & 0 \\
\hline
\end{tabular}

\section{0.-Hunted prey transport}

10.1.- How are hunted animals transported?

\begin{tabular}{ll}
\hline Inside a personal/private vehicle & 1 \\
\hline $\begin{array}{l}\text { In an exclusive vehicle or trailer with a refrigeration } \\
\text { system }\end{array}$ & 2 \\
\hline In the back of a pickup with canopy or enclosed trailer \\
\hline $\begin{array}{l}\text { In the back of an open pickup, open trailer, or on the roof } \\
\text { of a trailer }\end{array}$ & 0 \\
\hline Others (specify): & $D A^{*}$ \\
\hline * The score depends on the answer.
\end{tabular}

10.2.- Do you have authorization to transport ABP not intended for human consumption? (Animal by-Products)

\begin{tabular}{cl}
\hline YES & 1 \\
\hline NO & 0 \\
\hline
\end{tabular}

10.3.- How long does it normally take from the death of the animal until dressing?

\begin{tabular}{ll}
\hline The dressing is done immediately in the field & 3 \\
\hline Takes less than $2 \mathrm{~h}$. & 2 \\
\hline Takes between 2 and $4 \mathrm{~h}$. & 1 \\
\hline Takes between 4 and $6 \mathrm{~h}$. & 0 \\
\hline Takes between 6 and $8 \mathrm{~h}$. & 0 \\
\hline Takes more than $8 \mathrm{~h}$ & 0 \\
\hline Others (specify): & $D A^{*}$ \\
\hline
\end{tabular}

* The score depends on the answer.

11.- About personal hygiene and health protection while dressing

\section{1.- Do you wear any specific clothing to butcher?}

\begin{tabular}{lc}
\hline No, I use the same clothes as in the field & 0 \\
\hline Yes, I change all the clothes to use a specific clothing & 2 \\
\hline $\begin{array}{l}\text { I use covering clothes (such as a laboratory coat or a } \\
\text { coverall) }\end{array}$ & 1 \\
\hline I use specific footwear (such as rubber boots) & 1 \\
\hline Others (specify): & $D A^{*}$ \\
\hline
\end{tabular}

* The score depends on the answer.

11.2.- Do you use personal protective equipment (against cuts, pricks, inhalations ... ) during dressing (Several options can be marked if needed).

\begin{tabular}{lc}
\hline Disposable gloves & 1 \\
\hline Leather gloves & 1 \\
\hline Steel mesh gloves & 1 \\
\hline Facial mask & 1 \\
\hline Googles or face shield & 1 \\
\hline Others (specify): & $D A^{*}$ \\
\hline I do not use any protective equipment & 0
\end{tabular}

\footnotetext{
* The score depends on the answer.
} 
11.3.- The cutting tools (knives, kitchen scissors ... ) you use, are they specific for dressing game animals?

\begin{tabular}{ll}
\hline Yes, they are exclusive for game meat & 1 \\
\hline No, the tools are used in other tasks too & 0 \\
\hline
\end{tabular}

11.4.- Can you wash your hands while handling carcasses and viscera? (Several options can be marked if needed).

\begin{tabular}{ll}
\hline No, I cannot wash my hands immediately & 0 \\
\hline Yes, it is running water & 2 \\
\hline Yes, water coming from a water well, rainwater, etc. & 1 \\
\hline Yes, I use soap & 2 \\
\hline Yes, I use hand sanitizers & 2 \\
\hline Others (specify): & $D A^{*}$ \\
\hline
\end{tabular}

* The score depends on the answer.

12.- Ownership of the dressing site:

\begin{tabular}{l}
\hline Private own facilities \\
\hline Private facilities, owned by a different person \\
\hline Shared collective property (hunting club or similar) \\
\hline Public facilities, granted to hunters \\
\hline Others (specify): \\
\hline
\end{tabular}

\section{3.- Dressing facilities description: resources and infrastructures.}

\section{1.- Location}

\begin{tabular}{ll}
\hline Outdoors & 0 \\
\hline Indoors & 1 \\
\hline
\end{tabular}

13.2.- Do you use the room for other purposes besides game dressing? (Several options can be marked if needed).

\begin{tabular}{ll}
\hline $\begin{array}{l}\text { No, it is intended exclusively for the dressing of hunted } \\
\text { game }\end{array}$ & 2 \\
\hline Game dressing and pantry & 0 \\
\hline Game dressing and storage room & 1 \\
\hline Game dressing and garage & 1 \\
\hline Game dressing and workshop & 1 \\
\hline Game dressing and meeting place & 1 \\
\hline Game dressing and yard & 0 \\
\hline Game dressing and others (specify): & $D A^{*}$ \\
\hline
\end{tabular}

* The score depends on the answer.

13.3.- Where do you place the animals to slaughter them?

\begin{tabular}{lc}
\hline On the ground, on a dirt floor & 0 \\
\hline On the ground, over a plastic sheeting & 1 \\
\hline On the ground, on a pavement floor & 2 \\
\hline On a table or bench & 3 \\
\hline Hanging them & 4 \\
\hline Others (specify): & $D A^{*}$ \\
\hline
\end{tabular}

* The score depends on the answer.

\section{4.- Do you have water in the facility?}

\begin{tabular}{cc}
$\begin{array}{c}\text { Yes, hot and cold drinking } \\
\text { water }\end{array}$ & 3 \\
\hline Yes, cold drinking water & 2 \\
\hline $\begin{array}{c}\text { Yes, but it is not running } \\
\text { water (rainwater, water well) }\end{array}$ & 1 \\
\hline No & 0 \\
\hline
\end{tabular}


13.5.- What is the light source in the facility?

\begin{tabular}{ll}
\hline Sunlight & 1 \\
\hline Portable manual devices such as torches and headlamps & 2 \\
\hline Lighting provided by a portable electric generator & 3 \\
\hline Lighting provided by power grid and incandescent bulbs & 4 \\
\hline Lighting provided by power grid and halogen tubes & 4 \\
\hline Lighting provided by power grid and LED lights & 4 \\
\hline Others (specify): & $D A^{*}$ \\
\hline
\end{tabular}

* The score depends on the answer.

13.6.- Pest control (Several options can be marked if needed).

\begin{tabular}{ll}
\hline No control measures against insects & 0 \\
\hline No control measures against rodents & 0 \\
\hline Insect gauzes & 1 \\
\hline Insect light traps & 1 \\
\hline Insect adhesive traps & 1 \\
\hline Insecticide sprays & 1 \\
\hline Mouse spring trap & 1 \\
\hline Rodent cage traps & 1 \\
\hline Mouse glue traps & 1 \\
\hline Rat poison & 1 \\
\hline Others (specify): & $D A^{*}$ \\
\hline
\end{tabular}

* The score depends on the answer.

13.7.- How do you clean the facility after using it? (Several options can be marked if needed).

\begin{tabular}{ll}
\hline I do not clean the facility & 0 \\
\hline Hosing down & 1 \\
\hline Mopping the floor & 1 \\
\hline Dry brushing the floor & 0 \\
\hline Scouring pads for specific surfaces & 1 \\
\hline Use of bleach & 2 \\
\hline Use of caustic soda & 1 \\
\hline Use of ammonia & 1 \\
\hline Use of floor cleaners & 1 \\
\hline Use of soap & 1 \\
\hline Others (specify): & $D A^{*}$ \\
\hline
\end{tabular}

${ }^{*}$ The score depends on the answer.

13.8.- Wastewater elimination.

Through a specific organic wastewater treatment plant

Through the water network

To the outdoors (rivers, ravines, or crop fields)

Unknown

Others (specify):

* The score depends on the answer.

13.9.- Where are the butchered remains not intended for human consumption disposed of? (Several options can be marked if needed).

\begin{tabular}{ll}
\hline Directly in the field, in an open area & 0 \\
\hline Directly in the field, hidden in a pit cave, gully ... & 0 \\
\hline Directly in the field, in a burial plot & 1 \\
\hline Vulture feeding station & 1 \\
\hline Garbage containers & 1 \\
\hline Carcass containers & 2 \\
\hline Domestic dogs feeding & 0 \\
\hline Others (specify): & $D A^{*}$ \\
\hline
\end{tabular}

${ }^{*}$ The score depends on the answer. 


\section{References}

1. Tomasevic, I.; Novakovic, S.; Solowiej, B.; Zdolec, N.; Skunca, D.; Krocko, M.; Nedomova, S.; Kolaj, R.; Aleksiev, G.; Djekic, I. Consumers' perceptions, attitudes and perceived quality of game meat in ten European countries. Meat Sci. 2018, 142, 5-13. [CrossRef]

2. Higgs, J.D. The changing nature of red meat: 20 years of improving nutritional quality. Trends Food Sci. Technol. 2000, 11, 85-95. [CrossRef]

3. Nuernberg, K.; Nuernberg, G.; Dannenberger, D. Nutrient and lipid composition of muscle in wild animals. Fleischwirtschaft 2009, 89, 99-102.

4. $\quad$ Bureš, D.; Bartoň, L.; Kotrba, R.; Hakl, J. Quality attributes and composition of meat from Red Deer (Cervus Elaphus), Fallow Deer (Dama Dama) and Aberdeen Angus and Holstein Cattle (Bos Taurus). J. Sci. Food Agric. 2014, 95, 2299-2306. [CrossRef] [PubMed]

5. Ahl, A.S.; Nganwa, D.; Wilson, S. Public Health Considerations in human consumption of wild game. Ann. N. Y. Acad. Sci. 2006, 969, 48-50. [CrossRef]

6. Hoffman, L.C.; Wiklund, E. Game and Venison-Meat for the modern consumer. Meat Sci. 2006, 74, 197-208. [CrossRef]

7. Costa, H.; Mafra, I.; Oliveira, M.B.P.P.; Amaral, J.S. Game: Types and composition. In Encyclopedia of Food and Health; Caballero, B., Finglas, P., Toldrá, F., Eds.; Elsevier: Oxford, UK, 2016; Volume 3, pp. 177-183.

8. Brainerd, S. European Charter on Hunting and Biodiversity; Council of Europe Publishing: Strasbourg, France, 2007.

9. Tidball, K.G.; Tidball, M.M.; Curtis, P. Extending the locavore movement to wild fish and game: Questions and implications. Nat. Sci. Educ. 2013, 42, 185-189. [CrossRef]

10. Taylor, C.M.; Golding, J.; Emond, A.M. Intake of game birds in the UK: Assessment of the contribution to the dietary intake of lead by women of childbearing age and children. Public Health Nutr. 2014, 17, 1125-1129. [CrossRef]

11. INE. Instituto Nacional de Estadística. Cantidad Total y Cantidades Medias Consumidas de Alimentos, Bebidas, Tabaco, Combustibles y Otras Fuentes de Energía. Available online: http:/ / www.ine.es/jaxiT3/Datos.htm?t=25168 (accessed on 23 August 2019).

12. GfK Análisis de la Demanda de Carne de Caza en España. 2017. Available online: https://asiccaza.org/documentos/E-14484_ Informe_Demanda_Carne_de_Caza.pdf (accessed on 23 August 2019).

13. Gill, C.O. Microbiological conditions of meats from large game animals and birds. Meat Sci. 2007, 77, 149-160. [CrossRef]

14. Ramanzin, M.; Amici, A.; Casoli, C.; Esposito, L.; Lupi, P.; Marsico, G.; Mattiello, S.; Oliveri, O.; Ponzetta, M.P.; Russo, C.; et al. Meat from Wild Ungulates: Ensuring quality and hygiene of an increasing resource. Ital. J. Anim. Sci. 2010 , 9, e61.

15. Vieira-Pinto, M.; Coelho, C.; Vinhas, B.; Proença, J. Game meat hygiene and safety in Portugal. In Trends in Game Meat Hygiene: From Forest to Fork; Paulsen, P., Bauer, A., Smulders, F.J.M., Eds.; Wageningen Academic Publishers: Wageningen, The Netherlands, 2014; pp. 392-417.

16. Peruzy, M.F.; Murru, N.; Smaldone, G.; Proroga, Y.T.R.; Cristiano, D.; Fioretti, A.; Anastasio, A. Hygiene evaluation and microbiological hazards of hunted wild boar carcasses. Food Control 2022, 135, 108782. [CrossRef]

17. Atanassova, V.; Apelt, J.; Reich, F.; Klein, G. Microbiological quality of freshly shot game in Germany. Meat Sci. 2008, 78, 414-419. [CrossRef] [PubMed]

18. Paulsen, P.; Nagy, J.; Popelka, P.; Ledecky, V.; Marcinčák, S.; Pipová, M.; Smulders, F.J.M.; Hofbauer, P.; Lazar, P.; Dicakova, Z. Influence of storage conditions and shotshell wounding on the hygienic condition of hunted, uneviscerated pheasant (Phasianus colchicus). Poult. Sci. 2008, 87, 191-195. [CrossRef] [PubMed]

19. Falandysz, J.; Szymczyk-Kobrzyńska, K.; Brzostowski, A.; Zalewski, K.; Zasadowski, A. Concentrations of heavy metals in the tissues of Red Deer (Cervus Elaphus) from the region of Warmia and Mazury, Poland. Food Addit. Contam. 2005, 22, 141-149. [CrossRef]

20. Iqbal, S.; Blumenthal, W.; Kennedy, C.; Yip, F.Y.; Pickard, S.; Flanders, W.D.; Loringer, K.; Kruger, K.; Caldwell, K.L.; Brown, M.J Hunting with lead: Association between blood lead levels and wild game consumption. Environ. Res. 2009, 109, 952-959. [CrossRef]

21. Taggart, M.A.; Reglero, M.M.; Camarero, P.R.; Mateo, R. Should legislation regarding maximum Pb and Cd levels in Human food also cover large game meat? Environ. Int. 2011, 37, 18-25. [CrossRef]

22. Lehel, J.; Laczay, P.; Gyurcsó, A.; Jánoska, F.; Majoros, S.; Lányi, K.; Marosán, M. Toxic heavy metals in the muscle of Roe Deer (Capreolus capreolus)—Food toxicological significance. Environ. Sci. Pollut. Res. 2016, 23, 4465-4472. [CrossRef]

23. Deutz, A.; Völk, F.; Pless, P.; Fötschl, H.; Wagner, P. Wildfleischhygienische aspekte zu stöberjagden auf Rot-Und rehwild. Arch. Für Lebensm. 2006, 57, 197-202.

24. Gill, C.O. HACCP in the processing of fresh meat. In Improving the Safety of Fresh Meat; Elsevier: Cambridge, UK, 2005; pp. 630-672.

25. Orsoni, F.; Romeo, C.; Ferrari, N.; Bardasi, L.; Merialdi, G.; Barbani, R. Factors affecting the microbiological load of Italian hunted wild boar meat (Sus scrofa). Meat Sci. 2020, 160, 107967. [CrossRef]

26. Paleari, M.A.; Bersani, C.; Moretti Vittorio, M.; Beretta, G. Effect of curing and fermentation on the microflora of meat of various animal species. Food Control 2002, 13, 195-197. [CrossRef]

27. Paulsen, P.; Winkelmayer, R. Seasonal variation in the microbial contamination of game carcasses in an Austrian hunting area. Eur. J. Wildl. Res. 2004. [CrossRef]

28. Díaz-Sánchez, S.; Sánchez, S.; Sánchez, M.; Herrera-León, S.; Hanning, I.; Vidal, D. Detection and characterization of Shiga Toxin-producing Escherichia coli in game meat and ready-to-eat meat products. Int. J. Food Microbiol. 2012, 160, 179-182. [CrossRef] [PubMed] 
29. García-Sánchez, A.; Sánchez, S.; Rubio, R.; Pereira, G.; Alonso, J.M.; Hermoso de Mendoza, J.; Rey, J. Presence of Shiga Toxin-producing E. coli O157:H7 in a survey of wild artiodactyls. Vet. Microbiol. 2007, 121, 373-377. [CrossRef] [PubMed]

30. Literak, I.; Dolejska, M.; Radimersky, T.; Klimes, J.; Friedman, M.; Aarestrup, F.M.; Hasman, H.; Cizek, A. Antimicrobialresistant Faecal Escherichia coli in wild mammals in Central Europe: Multiresistant Escherichia coli Producing Extended-Spectrum Beta-Lactamases in Wild Boars. J. Appl. Microbiol. 2010, 108, 1702-1711. [CrossRef] [PubMed]

31. Meng, X.J.; Lindsay, D.S.; Sriranganathan, N. Wild boars as sources for infectious diseases in livestock and humans. Philos. Trans. R. Soc. B Biol. Sci. 2009, 364, 2697-2707. [CrossRef] [PubMed]

32. Mora, A.; López, C.; Dhabi, G.; López-Beceiro, A.M.; Fidalgo, L.E.; Díaz, E.A.; Martínez-Carrasco, C.; Mamani, R.; Herrera, A.; Blanco, J.E.; et al. Seropathotypes, phylogroups, Stx subtypes, and intimin types of wildlife-carried, Shiga Toxin-producing Escherichia coli strains with the same characteristics as Human-pathogenic isolates. Appl. Environ. Microbiol. 2012, 78, 2578-2585. [CrossRef]

33. Pozio, E.; Rinaldi, L.; Marucci, G.; Musella, V.; Galati, F.; Cringoli, G.; Boireau, P.; la Rosa, G. Hosts and habitats of Trichinella spiralis and Trichinella britovi in Europe. Int. J. Parasitol. 2009, 39, 71-79. [CrossRef]

34. Serracca, L.; Battistini, R.; Rossini, I.; Mignone, W.; Peletto, S.; Boin, C.; Pistone, G.; Ercolini, R.; Ercolini, C. Molecular investigation on the presence of Hepatitis E Virus (HEV) in wild game in North-Western Italy. Food Environ. Virol. 2015, 7, 206-212. [CrossRef]

35. Vieira-Pinto, M.; Morais, L.; Caleja, C.; Themudo, P.; Torres, C.; Igrejas, G.; Poeta, P.; Martins, C. Salmonella sp. in game (Sus scrofa and Oryctolagus cuniculus). Foodborne Pathog. Dis. 2011, 8, 739-740. [CrossRef]

36. Duda, M.D.; Nobile, J.L. The fallacy of online surveys: No data are better than bad data. Hum. Dimens. Wildl. 2010, 15, 55-64. [CrossRef]

37. Duda, M.D.; Jones, M. Public opinion on and attitudes toward hunting. In Proceedings of the Transactions of the Seventy-third North American Wildlife and Natural Resources Conference; Wildlife Management Institute: Washington, DC, USA, 2009.

38. Ljung, P.E.; Riley, S.J.; Heberlein, T.A.; Ericsson, G. Eat prey and love: Game-meat consumption and attitudes toward hunting. Wildl. Soc. Bull. 2012, 36, 669-675. [CrossRef]

39. Decker, D.J.; Stedman, R.C.; Larson, L.R.; Siemer, W.F. Hunting for wildlife management in America. Wildl. Prof. 2015,9 , 26-29.

40. Sevillano Morales, J.; Moreno-Ortega, A.; Amaro Lopez, M.A.; Arenas Casas, A.; Cámara-Martos, F.; Moreno-Rojas, R. Game meat consumption by hunters and their relatives: A probabilistic approach. Food Addit. Contam. Part A 2018, 35, 1739-1748. [CrossRef] [PubMed]

41. Duda, M.D.; Jones, M.F.; Criscione, A. Public awareness and credibility of Fish and Wildlife agencies in the Northeastern United States. Hum. Dimens. Wildl. 2009, 14, 142-144. [CrossRef]

42. Jay, L.S.; Comar, D.; Govenlock, L.D. A national Australian food safety telephone survey. J. Food Prot. 1999, 62, 921-928. [CrossRef]

43. Lagendijk, E.; Asseéré, A.; Derens, E.; Carpentier, B. Domestic refrigeration practices with emphasis on hygiene: Analysis of a survey and consumer recommendations. J. Food Prot. 2008, 71, 1898-1904. [CrossRef] [PubMed]

44. IVE. Instituto Valenciano de Estadística Estimacions de Població. Població Segons Sexe i Edat per Províncies. Available online: http:/ / externo6.gva.es/bdo/res_optimo.php (accessed on 20 August 2019).

45. Generalitat Valenciana. Conselleria de Agricultura, D.R.E.C. y T.E. Histórico de Licencias de Caza Hasta 2018. Available online: http:/ / www.agroambient.gva.es/es/web/medio-natural/estadisticas (accessed on 2 February 2019).

46. Colomé-Latorre, E.; González-López, E.; de Vicente y López, F.; Navarro-Baixauli, F. Plan de Acción Territorial Forestal de La Comunitat Valenciana-PATFOR. Documento Informativo o de Diagnosis. Elaborado Para: Dirección General del Medio Natural. Conselleria de Infraestructuras, Territorio y Medio Ambiente. Generalitat Valenciana. Valencia. Spain; Valencia. 2003. Available online: https://agroambient.gva.es/auto/montes-bosques/PATFOR/01_MEMORIA/PATFOR_Memoria_version_final.pdf (accessed on 27 September 2021).

47. DOGV-Diario Oficial de la Generalitat Valenciana Decreto 201/2017, de 15 de Diciembre, Del Consell, por el que se Regula la Venta de Proximidad de Productos Primarios y Agroalimentarios; Conselleria de Agricultura, Medio Ambiente, Cambio Climático y Desarrollo Rural-Conselleria de Sanidad Universal y Salud Pública. 2018. Available online: http://www.dogv.gva. es/datos/2018/02/20/pdf/2018_1589.pdf (accessed on 12 October 2021).

48. Vinhas, B.M.R. Sanitary Evaluation of large game hunted in Idanha-a-Nova County. Pilot study on evaluation of Sarcocystis spp. In Muscular Samples from Large Game Harvested for Human Consumption; Universidade de Trás-os-Montes e Alto Douro: Vila Real, Portugal, 2013.

49. Consellería de Sanidade, Xunta de Galicia; Organización Panamericana de la salud (OPS-OMS); Universidad CES, Colombia. Epidat: Programa para Análisis Epidemiológico de Datos. 2016. Available online: https://www.sergas.es/Saude-publica/ EPIDAT?idioma=es (accessed on 2 February 2019).

50. Backhans, A.; Fellström, C. Rodents on pig and chicken farms-A potential threat to human and animal health. Infect. Ecol. Epidemiol. 2012, 2, 17093. [CrossRef]

51. Bye, L.M. Masculinity and rurality at play in stories about hunting. Nor. Geogr. Tidsskr. Nor. J. Geogr. 2003, 57, 145-153. [CrossRef]

52. Smalley, A.L. "I just like to kill things": Women, men and the gender of sport hunting in the United States, 1940-1973. Gend. Hist. 2005, 17, 183-209. [CrossRef]

53. Ministerio de Cultura y Deporte (MCD) Anuario de Estadísticas Deportivas. 2020. Available online: https://www. culturaydeporte.gob.es/dam/jcr:47414879-4f95-4cae-80c4-e289b3fbced9/anuario-de-estadisticas-deportivas-2020.pdf (accessed on 6 February 2021). 
54. Kirk, S.F.L.; Greenwood, D.; Cade, J.E.; Pearman, A.D. Public perception of a range of potential food risks in the United Kingdom. Appetite 2002, 38, 189-197. [CrossRef]

55. Sharif, L.; Al-Malki, T. Knowledge, Attitude and practice of Taif University students on food poisoning. Food Control 2010, 21, 55-60. [CrossRef]

56. Redmond, E.C.; Griffith, C.J.; Slader, J.; Humphrey, T.J. Microbiological and observational analysis of cross contamination risks during domestic food preparation. Br. Food J. 2004, 106, 581-597. [CrossRef]

57. Mensah, P.; Yeboah-Manu, D.; Owusu-Darko, K.; Ablordey, A.; Nkurmah, F.K.; Kamiya, H. The role of street food vendors in the transmission of enteric pathogens. Ghana Med. J. 1999, 33, 19-29.

58. Sudershan, R.V.; Rao, G.M.S.; Rao, P.; Rao, M.V.V.; Polasa, K. Food safety related perceptions and practices of mothers-A Case Study in Hyderabad, India. Food Control 2008, 19, 506-513. [CrossRef]

59. Ababio, P.F.; Adi, D.D. Evaluating food hygiene awareness and practices of food handlers in the Kumasi metropolis. Internet J. Food Saf. 2012, 14, 35-43.

60. Garayoa, R.; Córdoba, M.; García-Jalón, I.; Sanchez-Villegas, A.; Vitas, A.I. Relationship between consumer food safety knowledge and reported behavior among students from health sciences in one region of Spain. J. Food Prot. 2005, 68, 2631-2636. [CrossRef]

61. Esteve, C.; Nieto, M.P. Estadísticas Cinegéticas de la Comunitat Valenciana. Memoria 2018 (Temporada 2017/2018); Generalitat Valenciana, Conselleria d'Agricultura, Desenvolupament rural, Emergècia Cimàticai Transició Ecològica: Valencia, Spain, 2019.

62. Alberto, J.R.; Serejo, J.P.; Vieira-Pinto, M. Dog Bites in Hunted Large Game: A hygienic and economical problem for game meat production. In Game Meat Hygiene in Focus; Paulsen, P., Bauer, A., Vodnansky, M., Winkelmayer, R., Smulders, F.J.M., Eds.; Wageningen Academic Publishers: Wageningen, The Netherlands, 2011; pp. 101-105.

63. Gari-Toussaint, M.; Tieulié, N.; Baldin, J.L.; Dupouy-Camet, J.; Delaunay, P.; Fuzibet, J.G.; le Fichoux, Y.; Pozio, E.; Marty, P. Human trichinellosis due to Trichinella britovi in Southern France after consumption of frozen wild boar meat. Eurosurveillance 2005, 10, 11-12. [CrossRef]

64. Wichmann, O.; Schimanski, S.; Koch, J.; Kohler, M.; Rothe, C.; Plentz, A.; Jilg, W.; Stark, K. Phylogenetic and case-control study on Hepatitis E Virus infection in Germany. J. Infect. Dis. 2008, 198, 1732-1741. [CrossRef]

65. Rivero-Juarez, A.; Frias, M.; Martinez-Peinado, A.; Risalde, M.A.; Rodriguez-Cano, D.; Camacho, A.; García-Bocanegra, I.; Cuenca-Lopez, F.; Gomez-Villamandos, J.C.; Rivero, A. Familial hepatitis E outbreak linked to wild boar meat consumption. Zoonoses Public Health 2017, 64, 561-565. [CrossRef]

66. European Union Regulation (EC) No 853/2004 of the European Parliament and of the Council of 29 April 2004 Laying down Specific hygiene rules for on the hygiene of foodstuffs. Off. J. Eur. Union 2004, 2004, 55-205.

67. DOGV-Diario Oficial de la Generalitat Valenciana Orden 3/2019 de 12 de Julio, de la Conselleria de Sanidad Universal y Salud Pública Sobre la Habilitación de Veterinarios Para el Control Sanitario de Pequeñas Cantidades de Carne de Caza Silvestre. Generalitat Valenciana. Conselleria de Sanidad Universal y Salud Pública. 2019. Available online: http://www.dogv.gva.es/ datos/2019/08/01/pdf/2019_7607.pdf (accessed on 1 November 2021).

68. European Union Regulation (EC). No 1069/2009 of the European Parliament and of the Council of 21 October 2009 Laying down Health Rules as Regards Animal by-Products and Derived Products Not Intended for Human Consumption and Repealing Regulation (EC) No 1774/2002; Official Journal of the European Union (OJEU): Luxembourg, 2009; pp. 1-33.

69. DOGV—Diario Oficial de la Generalitat Valenciana. ORDEN 22/2021, de 11 de Noviembre, de la Conselleria de Agricultura, Desarrollo Rural, Emergencia Climática y Transición Ecológica, por la que se Regula la Caza y Control del Jabalí en la Comunitat Valenciana. Generalitat Valenciana. Conselleria de Agricultura, Desarrollo Rural, Emergencia Climática y Transición Ecológica. 2021. Available online: https:/ /dogv.gva.es/datos/2021/11/19/pdf/2021_11576.pdf (accessed on 6 December 2021).

70. Winkelmayer, R.; Paulsen, P.; Lebersorger, P.; Zedka, H.F. Jagdmethode und Trefferlage. In Wildbret-Hygiene, Das Buch Zur Guten Hygienepraxis Bei Wild; Winkelmayer, R., Paulsen, P., Lebersorger, P., Zedka, H.F., Eds.; Zentralstelle Österreichischer Landesjagtverbände: Wien, Austria, 2008; pp. 69-75. ISBN 978-3-9501873-8-0.

71. Avagnina, A.; Nucera, D.; Grassi, M.A.; Ferroglio, E.; Dalmasso, A.; Civera, T. The microbiological conditions of carcasses from large game animals in Italy. Meat Sci. 2012, 91, 266-271. [CrossRef] [PubMed]

72. Karimi, A.; al Borzi, A.; Rasouli, M.; Kadivar, M.R.; Nateghian, A.R. Prevalence of antibody to Brucella species in butchers, slaughterers and others. EMHJ East. Mediterr. Health J. 2003, 9, 178-184. [CrossRef] [PubMed]

73. Barker, J.; Naeeni, M.; Bloomfield, S.F. The effects of cleaning and disinfection in reducing Salmonella contamination in a laboratory model kitchen. J. Appl. Microbiol. 2003, 95, 1351-1360. [CrossRef] [PubMed]

74. Corry, J.E.L.; Hinton, M.H. Zoonoses in the meat industry: A review. Acta Veterinaria Hungarica 1997, 45, 457-479.

75. Starnes, C.T.; Talwani, R.; Horvath, J.A.; Duffus, W.A.; Bryan, C.S. Brucellosis in two hunt club members in South Carolina. J. South Carol. Med. Assoc. 2004, 100, 113-115.

76. Schneider, R.C.; Santos, M.D.; Lunardi, M.; Benetti, A.H.; Camargo, L.M.; Freitas, S.H.; Negreiro, R.L.; Costa, D.S. Prevalence of brucellosis and risk factors associated with its transmission to slaughterhouse employees in the Cuiaba metropolitan area in the State of Mato Grosso. Semin. Ciências Agrárias 2013, 34, 2367. [CrossRef]

77. Deutz, A.; Fuchs, K.; Auer, H.; Kerbl, U.; Aspöck, H.; Köfer, J. Toxocara-infestations in Austria: A study on the risk of infection of farmers, slaughterhouse staff, hunters and veterinarians. Parasitol. Res. 2005, 97, 390-394. [CrossRef]

78. Wolfe, N.D.; Dunavan, C.P.; Diamond, J. Origins of major human infectious diseases. Nature 2007, 447, 279-283. [CrossRef]

79. Vasconcellos, J.A. Quality Assurance for the Food Industry; CRC Press: Boca Raton, FL, USA, 2003; ISBN 9780203498101. 
80. CEN/CENELEC European Committee for Standardization and European Committee for Electrotechnical Standardization Light and Lighting_Lighting of work places-Part 1: Indoor work places. Available online: https://standards.cencenelec.eu/dyn/ www /f?p=CEN:110:0::::FSP_PROJECT:30549\&cs=1DFE69E8345FF5C30850851582FF2D3D5 (accessed on 8 November 2021).

81. Olsen, A.R.; Hammack, T.S. Isolation of Salmonella spp. from the housefly, Musca domestica L., and the dump fly, Hydrotaea aenescens (Wiedemann) (Diptera: Muscidae), at caged-layer houses. J. Food Prot. 2000, 63, 958-960. [CrossRef]

82. Romero-Barrios, P.; Hempen, M.; Messens, W.; Stella, P.; Hugas, M. Quantitative microbiological risk assessment (QMRA) of food-borne zoonoses at the European level. Food Control 2013, 29, 343-349. [CrossRef]

83. Herman, L.; Heyndrickx, M.; Grijspeerdt, K.; Vandekerchove, D.; Rollier, I.; de Zutter, L. Routes for Campylobacter contamination of poultry meat: Epidemiological study from hatchery to slaughterhouse. Epidemiol. Infect. 2003, 131, 1169-1180. [CrossRef] [PubMed]

84. Backhans, A.; Fellström, C.; Lambertz, S.T. Occurrence of pathogenic Yersinia enterocolitica and Yersinia pseudotuberculosis in small wild rodents. Epidemiol. Infect. 2011, 139, 1230-1238. [CrossRef] [PubMed]

85. Webster, J.P.; MacDonald, D.W. Cryptosporidiosis reservoir in wild brown rats (Rattus Norvegicus) in the UK. Epidemiol. Infect. 1995, 115, 207-209. [CrossRef] [PubMed]

86. Margni, M.; Rossier, D.; Crettaz, P.; Jolliet, O. Life cycle impact assessment of pesticides on human health and ecosystems. Agric. Ecosyst. Environ. 2002, 93, 379-392. [CrossRef]

87. Hagstrum, D.W.; Dowdy, A.K.; Lippert, G.E. Early detection of insects in stored wheat using sticky traps in bin headspace and prediction of infestation level. Environ. Entomol. 1994, 23, 1241-1244. [CrossRef]

88. Schlundt, J.; Toyofuku, H.; Jansen, J.; Herbst, S.A. Emerging food-borne zoonoses. Rev. Sci. Et Tech.-Off. Int. Des Epizoot. 2004, 23, 513-533. [CrossRef] [PubMed]

89. Lalla, F.; Dingle, P. The efficacy of cleaning products on food industry surfaces. J. Environ. Health 2004, 67, 17-22.

90. Taormina, P.J.; Dorsa, W.J. Evaluation of hot-water and sanitizer dip treatments of knives contaminated with bacteria and meat residue. J. Food Prot. 2007, 70, 648-654. [CrossRef]

91. Hughes, J.M.; Colley, D.G.; Lopez, A.; Dietz, V.J.; Wilson, M.; Narvin, T.R.; Jones, J.L. Preventing congenital Toxoplasmosis. Morbility Mortal. Wkly. Rep. Recomm. Rep. 2000, 49, 57-75.

92. Bauermann Brasil, C.C.; Smanioto Barin, J.; Jacob-Lopes, E.; Ragagnin Menezes, C.; Queiroz Zepka, L.; Wagner, R.; Bastianello Campagnol, P.C.; Cichoski, A.J. Single Step non-thermal cleaning/sanitation of knives used in meat industry with ultrasound. Food Res. Int. 2017, 91, 133-139. [CrossRef]

93. Stewart, P.S. Multicellular Nature of Biofilm Protection from Antimicrobial Agents. In Biofilm Communities: Order from Chaos; McBain, A., Allison, D., Brading, M., Rickard, A., Verran, J., Walker, J., Eds.; Bioline: Cardiff, UK, 2003; pp. 181-190.

94. Burfoot, D.; Reavell, S.; Tuck, C.; Wilkinson, D. Generation and dispersion of droplets from cleaning equipment used in the chilled food industry. J. Food Eng. 2003, 58, 343-353. [CrossRef]

95. Gibson, H.; Taylor, J.H.; Hall, K.E.; Holah, J.T. Effectiveness of cleaning techniques used in the food industry in terms of the removal of bacterial biofilms. J. Appl. Microbiol. 1999, 87, 41-48. [CrossRef] [PubMed]

96. Romanova, N.; Favrin, S.; Griffiths, M.W. Sensitivity of Listeria monocytogenes to sanitizers used in the meat processing industry. Appl. Environ. Microbiol. 2002, 68, 6405-6409. [CrossRef] [PubMed]

97. Gómez, D.; Ariño, A.; Carramiñana, J.J.; Rota, C.; Yangüela, J. Sponge versus mini-roller for the surface microbiological control of Listeria monocytogenes, total aerobic mesophiles and enterobacteriaceae in the meat industry. Food Control 2012, 27, 242-247. [CrossRef]

98. Watkinson, W.J. Laboratory Test methods. In Cleaning-in-Place: Dairy, Food and Beverage Operations; Tamine, A.Y., Ed.; John Wiley \& Sons: Hoboken, NJ, USA, 2009; pp. 59-65.

99. Ehavald, H.; Šalej, A.; Caliskan, H.; Aksan, E.; Karpíšková, S.; Kabak, B.; Weiss, M.; Agel, E.; Karahan, G. Food Process Hygiene, Effective cleaning and safety in the food industry. In Microbial Contaminants and Contamination Routes in Food Industry; VTT: Espoo, Finland, 2007; pp. 129-144. ISBN 978-951-38-6319-7.

100. Saravanan, P.; Sathish Kumar, S. Food-safety and quality maintenance. Int. J. Eng. Sci. 2013, 2, $206-208$.

101. Combs, M.; Byers, K.A.; Ghersi, B.M.; Blum, M.J.; Caccone, A.; Costa, F.; Himsworth, C.G.; Richardson, J.L.; Munshi-South, J. Urban rat races: Spatial population genomics of brown rats (Rattus norvegicus) compared across multiple cities. In The Evolution of City Life; Johnson, M.T.J., Rivkin, L.R., Santangelo, J.S., Eds.; The Royal Society Publishing: London, UK, 2018.

102. Contesse, P.; Hegglin, D.; Gloor, S.; Bontadina, F.; Deplazes, P. The diet of urban foxes (Vulpes vulpes) and the availability of anthropogenic food in the city of Zurich, Switzerland. Mamm. Biol. 2004, 69, 81-95. [CrossRef]

103. Denny, E.; Yakovlevich, P.; Eldridge, M.D.B.; Dickman, C. Social and genetic analysis of a population of free-living cats (Felis catus L.) exploiting a resource-rich habitat. Wildl. Res. 2002, 29, 405. [CrossRef]

104. Lass, A.; Pietkiewicz, H.; Modzelewska, E.; Dumètre, A.; Szostakowska, B.; Myjak, P. Detection of Toxoplasma gondii oocysts in environmental soil samples using molecular methods. Eur. J. Clin. Microbiol. Infect. Dis. 2009, 28, 599-605. [CrossRef]

105. Lizana, V.; Gortázar, C.; Muniesa, A.; Cabezón, Ó.; Martí-Marco, A.; López-Ramon, J.; Cardells, J. Human and environmental factors driving Toxoplasma gondii prevalence in wild boar (Sus scrofa). Res. Vet. Sci. 2021, 141, 56-62. [CrossRef]

106. Pérez-Martín, J.E.; Serrano, F.J.; Reina, D.; Mora, J.A.; Navarrete, I. Sylvatic trichinellosis in Southwestern Spain. J. Wildl. Dis. 2000, 36, 531-534. [CrossRef] 
107. Pozio, E.; Casulli, A.; Bologov, V.V.; Marucci, G.; la Rosa, G. Hunting practices increase the prevalence of Trichinella infection in wolves from European Russia. J. Parasitol. 2001, 87, 1498-1501. [CrossRef]

108. Carrasco-Garcia, R.; Barroso, P.; Perez-Olivares, J.; Montoro, V.; Vicente, J. Consumption of big game remains by scavengers: A potential risk as regards disease transmission in Central Spain. Front. Vet. Sci. 2018, 5, 4. [CrossRef] [PubMed]

109. Zamora, M.J.; Alvarez, M.; Olmedo, J.; Blanco, M.C.; Pozio, E. Trichinella pseudospiralis in the Iberian Peninsula. Vet. Parasitol. 2015, 210, 255-259. [CrossRef] [PubMed]

110. Pozio, E. Trichinellosis in the European Union: Epidemiology, ecology and economic impact. Parasitol. Today 1998, 14, 35-38. [CrossRef]

111. Pozio, E. The opportunistic nature of Trichinella-Exploitation of new geographies and habitats. Vet. Parasitol. 2013, 194, 128-132. [CrossRef] [PubMed]

112. Pozio, E. Factors affecting the flow among domestic, synanthropic and sylvatic cycles of Trichinella. Vet. Parasitol. 2000, 93, $241-262$. [CrossRef]

113. Pérez Pérez, V.; Cuesta, N.; Millán, L.; Ferreras, M.d.C. Enfermedad de Aujeszky en la especie canina: Descripción clínica y lesional de tres casos. In Proceedings of the XXXI Reunión de la Sociedad Española de Anatomía Patológica Veterinaria (SEAPV) Puerto de la Cruz, Tenerife, Spain, 12 June 2019.

114. Möhl, K.; Große, K.; Hamedy, A.; Wüste, T.; Kabelitz, P.; Lücker, E. Biology of Alaria spp. and human exposition risk to Alaria mesocercariae-A review. Parasitol. Res. 2009, 105, 1. [CrossRef]

115. Gazzonis, A.L.; Villa, L.; Riehn, K.; Hamedy, A.; Minazzi, S.; Olivieri, E.; Zanzani, S.A.; Manfredi, M.T. Occurrence of selected zoonotic food-borne parasites and first molecular identification of Alaria alata in wild boars (Sus scrofa) in Italy. Parasitol. Res. 2018, 117, 2207-2215. [CrossRef]

116. Jiménez, S.; Pérez, A.; Gil, H.; Schantz, P.M.; Ramalle, E.; Juste, R.A. Progress in control of cystic echinococcosis in La Rioja, Spain: Decline in infection prevalences in human and animal hosts and economic costs and benefits. Acta Tropica 2002, 83, $213-221$. [CrossRef]

117. Mateus, T.L.; Gargaté, M.J.; Vilares, A.; Ferreira, I.; Rodrigues, M.; Coelho, C.; Vieira-Pinto, M. First report of Echinococcus ortleppi in free-living wild boar (Sus scrofa) from Portugal. Microorganisms 2021, 9, 1256. [CrossRef]

118. Arias, M.; Jurado, C.; Gallardo, C.; Fernández-Pinero, J.; Sánchez-Vizcaíno, J.M. Gaps in African Swine Fever: Analysis and priorities. Transbound. Emerg. Dis. 2018, 65, 235-247. [CrossRef]

119. Worley, D.E.; Seesee, F.M.; Zarlenga, D.S.; Murrell, K.D. Attempts to eradicate trichinellosis from a wild boar population in a private game park. In Trichinellosis; Campbell, C.W., Pozio, E., Bruschi, F., Eds.; Istituto Superiore di Sanità Press: Rome, Italy, 1994; pp. 611-616.

120. Ogada, D.L.; Torchin, M.E.; Kinnaird, M.F.; Ezenwa, V.O. Effects of vulture declines on facultative scavengers and potential implications for mammalian disease transmission. Conserv. Biol. 2012, 26, 453-460. [CrossRef] [PubMed]

121. Margalida, A.; Donázar, J.A.; Carrete, M.; Sánchez-Zapata, J.A. Sanitary versus Environmental Policies: Fitting together two pieces of the puzzle of European Vulture Conservation. J. Appl. Ecol. 2010, 47, 931-935. [CrossRef]

122. Abubakar, I.; Myhill, D.J.; Hart, A.R.; Lake, I.R.; Harvey, I.; Rhodes, J.M.; Robinson, R.; Lobo, A.J.; Probert, C.S.J.; Hunter, P.R A case-control study of drinking water and dairy products in Crohn's disease-Further investigation of the possible role of Mycobacterium avium paratuberculosis. Am. J. Epidemiol. 2007, 165, 776-783. [CrossRef] [PubMed]

123. Naranjo, V.; Gortazar, C.; Vicente, J.; de la Fuente, J. Evidence of the role of European Wild boar as a reservoir of Mycobacterium tuberculosis Complex. Vet. Microbiol. 2008, 127, 1-9. [CrossRef]

124. Grant, I.R. Mycobacterium avium subsp. paratuberculosis in animal-derived foods and the environment. In Paratuberculosis Organism, Disease, Control; Behr, M., Collins, D.M., Eds.; CAB International: Cambridge, UK, 2010; pp. 29-39.

125. Villena, I.; Aubert, D.; Gomis, P.; Ferté, H.; Inglard, J.-C.; Denis-Bisiaux, H.; Dondon, J.-M.; Pisano, E.; Ortis, N.; Pinon, J.-M. Evaluation of a strategy for Toxoplasma gondii oocyst detection in water. Appl. Environ. Microbiol. 2004, 70, 4035-4039. [CrossRef]

126. Rutjes, S.A.; Lodder, W.J.; Lodder-Verschoor, F.; van den Berg, H.H.J.L.; Vennema, H.; Duizer, E.; Koopmans, M.; de Roda Husman, A.M. Sources of Hepatitis E Virus Genotype 3 in the Netherlands. Emerg. Infect. Dis. 2009, 15, 381-387. [CrossRef]

127. Steyer, A.; Naglič, T.; Močilnik, T.; Poljšak-Prijatelj, M.; Poljak, M. Hepatitis E Virus in domestic Pigs and surface waters in Slovenia: Prevalence and molecular characterization of a novel genotype 3 lineage. Infect. Genet. Evol. 2011, 11, $1732-1737$. [CrossRef]

128. Rashid, A.A.; Khayoon, S.Q.; Al-Tufaili, R.A.N. Investigation of parasitic contamination in Kufa River Water-Al-Najaf Province. Mag. Al-Kufa Univ. Biol. 2014, 6, 37-48.

129. Richard, S.; Oppliger, A. Zoonotic occupational diseases in forestry workers-Lyme Borreliosis, Tularemia and Leptospirosis in Europe. Ann. Agric. Environ. Med. 2015, 22, 43-50. [CrossRef]

130. Tokarska-Rodak, M.; Plewik, D.; Michalski, A.J.; Kolodziej, M.; Melgies, A.; Panczuk, A.; Konon, H.; Niemcewicz, M. Serological surveillance of vector-borne and zoonotic diseases among hunters in Eastern Poland. J. Vector Borne Dis. 2016, 53, 355-361. 